Bei 120 Patienten wurden zur Klärung der Frage thrombotischer Prozesse phlebographische Röntgenuntersuchungen der oberen Körperhälfte durchgeführt. Es handelte sich um Früh- und Spätuntersuchungen. 28\% der Patienten hatten thrombotische Veränderungen im Subclavia-Venenwinkelbereich. Nur 5\% zeigten klinisch eine Armschwellung und Hautvenenerweiterungen.

Embolische Lungenkomplikationen durch Thrombenablösung entlang der Elektroden wurden klinisch in keinem Fall, bei Obduktionen nur in 2 Fällen gesehen. Eine tödliche Lungenembolie wurde überhaupt nicht nachgewiesen.

Phlebographische Untersuchungen sind indiziert, wenn Elektrodenextraktionen bzw. Elektrodenlagekorrekturen vorgesehen sind, da bei nachgewiesenen Thromben mit deren Ablösung oder mit Venenverletzungen zu rechnen ist.

\title{
177. Ergebnisse der Schrittmacher-Dauerbehandlung
}

\author{
K. ReeH*, F. RotThoff und G. Hopf-Kassel

\section{Results of Long-Term Pacemaker Therapy}

Summary. Since 1966 a total of 199 pacemakers were implanted in 133 patients. 97 of these patients are alive to-day. To reduce the surgical risk and enable us to carry out the operation even if the patient's general condition is poor, we prefer the insertion of an endocardial electrode. Further advantages of this method are the easily-acquired technique, the slow increase in the stimulus threshold (electrodetissue resistance) and with it the longer functional life of the device. With increasing mastery of the technique, the number of post-operative complications, particularly displacement of the electrodes, is diminished. A further decrease in the number of cases where repositioning is necessary due to dislocation of the point of the electrode, will be achieved by improving the electrodes, so that the use of a myocardial electrode, with its many disadvantages, will only rarely be necessary.

In several cases where tissue intolerance of the pacemaker occurred, the pacemaker was introduced in a pocket made of lyophylized dura, and good results were obtained with this.

Zusammenfassung. Seit 1966 wurden bei 133 Patienten insgesamt 199 Schrittmacher implantiert. Bis heute leben 97 Patienten. Wegen der Vorteile des geringen Operationsrisikos und des damit auch bei schlechtem Allgemeinzustand zumutbaren Eingriffes bevorzugen wir zur definitiven Versorgung die endokardiale Elektrode. Weitere Vorzüge dieser Methode sind die leicht erlernbare Technik sowie die geringe Reizschwellenzunahme und die damit längere Funktionsdauer des Aggregates. Mit zunehmender Beherrschung des Eingriffes ist die Zahl der postoperativen Komplikationen, insbesondere der Elektrodenplazierung, seltener geworden. Eine weitere Senkung der Revisionen wegen Dislokation der Elektrodenspitze wird durch Verbesserung der Elektroden möglich sein, so daß nur noch in seltenen Fällen die mit zahlreichen Nachteilen behaftete myokardiale Elektrode angezeigt ist. In mehreren Fällen konnten bei Gewebeunverträglichkeit des Schrittmachers durch Einbringen desselben in eine Tasche aus lyophylisierter Dura gute Erfolge erzielt werden. 